\title{
Barrier effects of roads on an endangered forest obligate: influences of traffic, road edges,
} and gaps

Hsiang Ling Chen ${ }^{1 *}$, John L. Koprowski ${ }^{1}$

${ }^{1}$ School of Natural Resources and the Environment, The University of Arizona, N335

Environment and Natural Resources 2, 1064 East Lowell Street, Tucson, AZ 85721, USA.

* Corresponding author

E-mail: cherlene@,email.arizona.edu

Tel: +1 520-465-0436

\section{Abstract}

Habitat fragmentation and destruction caused by development of infrastructure such as roads threaten biodiversity. Roads act as barriers by impeding animal movements and restricting space use. Understanding factors that influence barrier effects is important to discern the impacts of habitat fragmentation and to develop appropriate mitigations. We combined telemetry and demographic data in 2008 to 2012 with remote sensing imagery to investigate barrier effects of forest roads and assess effects of traffic, road edges, and canopy gaps on space use of an endangered, endemic forest obligate, the Mt. Graham red squirrel (Tamiasciurus hudsonicus grahamensis). We mapped low to high traffic roads, road edges, canopy gaps, and random lines in forests to serve as references. We determined if red squirrels included these linear features in their total and core home ranges, and used this metric as an indicator of crossing and preference for habitat adjacent to the linear features. Forest roads acted as barriers regardless of traffic volume and had long-term impacts on animal space use. Animals did not avoid entering roadside areas, and probability of crossing linear features in the forest was not affected by distance to roads. In contrast, greater canopy cover increased probability of crossing, and gaps in canopy impeded animal movements. Higher likelihood of road crossing was associated with more variable tree height and mating activity. We demonstrated that narrow forest roads with low traffic volume were barriers for forest dependent species, and suggest that gap avoidance inhibits road crossings.

Keywords: habitat fragmentation, gap avoidance, forest roads, forest structure, small mammals, road impacts

\section{Introduction}

Habitat fragmentation and destruction caused by development of infrastructure such as roads and bridges are recognized as major threats to biodiversity (Czech and Krausman, 1997; Forman and Alexander, 1998). To maintain habitat connectivity, genetic variability, and population persistence, the facilitation of movements of animals through landscapes is critical (Frankham, 1996; Hanski and Gilpin, 1991). Roads and traffic can serve as barriers that impede animal movements, decrease accessibility of resources such as food, shelter or mates, lead to reduction in reproductive success and gene flow, and ultimately threaten population persistence (Strasburg, 2006; Trombulak and Frissell, 2000). Barrier effects of roads have been documented in a diversity of terrestrial fauna, including insects (Bhattacharya et al., 2003), reptiles (Shepard et al., 2008), amphibians (Marsh et al., 2005), birds (Laurance et al., 2004) and mammals (Burnett, 1992), but the causes and mechanisms of road avoidance are not fully understood (Bissonette and Rosa, 2009; Chen and Koprowski, 2013; Roedenbeck et al., 2007).

The barrier effects of roads are driven by several distinct but not mutually exclusive mechanisms that include traffic, edge, and gap avoidance (Barber et al., 2010; Forman et al., 2003; Greenberg, 1989; Jaeger et al., 2005). Traffic avoidance includes avoidance of vehicles as well as traffic disturbance that arises from vehicular noise, movements, vibration, exhaust fumes, 
dust, headlight illumination and human presence, and has been related to reduction in animal abundance at roadside areas (Barber et al., 2010; Goosem, 2002). Edge avoidance results when animals avoid entering roadside areas due to physical and biotic changes caused by an abrupt transition of ground surface or vegetation (Ford and Lenore, 2008; Forman et al., 2003). Edge effects due to roads can affect the distribution, density and abundance of wildlife in adjacent habitat (Goosem, 2000). Yet, how road edges impact animal movements and space use has been assessed less frequently. Gap avoidance occurs when species avoid clearings with low canopy or understory closure such as roads and forest clearcuts, perhaps because of increased predation risk (Greenberg, 1989) and evolutionary constraints (Laurance et al., 2004).

One fundamental question in road ecology is "what is the relative importance of the different mechanisms by which roads affect population persistence?" (Roedenbeck et al., 2007). Effects of roads on animal populations depend on species life history traits as well as behavioral responses to roads (Benítez-López et al., 2010; Jaeger et al., 2005; Rytwinski and Fahrig, 2012). Previous research on barrier effects has focused on one or two of these potential mechanisms contributing to road avoidance. However, to comprehensively understand barrier effects of roads and develop appropriate mitigation, studies that simultaneously address the relative importance of these different mechanisms are needed. For example, barrier effects of roads due to road avoidance should be distinguished clearly from the effects due to road mortality, as both causes lead to reduced individuals cross roads, but the mechanisms are fundamentally different and require different mitigation (Fahrig and Rytwinski, 2009). Both avoidance of vehicles and avoidance of traffic disturbance result in a decreased rate of road crossings, but avoidance of traffic disturbance can also lead to reduction in animal abundance at roadside areas (Forman and Alexander, 1998; Jaeger et al., 2005).

Tree squirrels (Sciurus and Tamiasciurus) are an ideal group for assessing the impacts of roads on forest dependent species. Arboreal squirrels are widespread, common, and are readily sampled and tracked by radio telemetry because of moderate home range size (Gurnell and Pepper, 1994; Koprowski et al., 2008). Previously, barrier effects of roads have been assessed primarily by capture-recapture methods and translocation (e.g. McDonald \& St Clair 2004). Although such techniques increase understanding of road crossing behavior by highly motivated individuals, the pattern of spontaneous movements or the relationship between home range boundaries and roads is difficult to discern (Ford and Lenore, 2008; Laurance et al., 2004). Techniques like radio telemetry that quantify individual movements can alleviate these issues (Clark et al., 2001). Herein, we combine long-term radio telemetry data and traffic monitoring with high-resolution remote sensing data to examine barrier effects of roads and traffic on animal space use and movements. We use an endangered, endemic forest obligate - the Mt. Graham red squirrel (Tamiasciurus hudsonicus grahamensis) as a model to (1) investigate whether forest roads are barriers and assess the relative importance of traffic, edge, and gap avoidance, and (2) examine factors that influence animal movements and identify environmental features and road characteristics that may improve road permeability.

\section{Material and methods}

$87 \quad 2.1$ Study area and study species

Our study was conducted in 342 ha of mixed-conifer forest $>3,000$ m elevation in the Pinaleño Mountains (Graham Mountains), Graham County, Arizona, USA

$90 \quad\left(32^{\circ} 42^{\prime} 06^{\prime \prime} \mathrm{N}, 109^{\circ} 52^{\prime} 17^{\prime \prime} \mathrm{W}\right)$. We used bi-directional traffic counters (TRAFx Vehicle

91 Counter Model G3, TRAFx Research Ltd, Canmore, Alberta, Canada) to monitor $6.6 \mathrm{~km}$ of 4

92 graded dirt roads (Fig.1a): Arizona State Highway 366 also known as Swift Trail (6 to13-m wide, 
annual average daily traffic [AADT]: 50 vehicles, hereafter, high traffic), the access road to the Mount Graham International Observatory (4 to10-m wide, AADT: 23 vehicles, hereafter, medium traffic), the Bible Camp Road (4 to 9-m wide, AADT: 25 vehicles, hereafter, medium traffic), and Soldier Trail (3 to 24-m wide, AADT: 7 vehicles, hereafter, low traffic). Speed limit was $40 \mathrm{~km} / \mathrm{h}$. Roads were closed to the public from 15 November to 15 April annually. No wildlife road crossing structures were installed in the study area. The forest is dominated by Douglas-fir (Pseudotsuga menziesii), southwestern white pine (Pinus strobiformis), and corkbark fir (Abies lasiocarpa var. arizonica) interspersed with Engelmann spruce (Picea engelmanii), aspen (Populus tremuloides) and ponderosa pine (Pinus ponderosa, Sanderson \& Koprowski 2009).

The North American red squirrel is a small $(<300 \mathrm{~g})$, diurnal tree squirrel with a wideranging distribution in Canada and the United States (Steele, 1998). Red squirrels are territorial and center their territories on conspicuous cone-scale piles with cones in caches known as middens (Gurnell, 1987; Steele, 1998). Middens are typically located in forests with dense canopy and understory cover and provide a cool and moist microclimate that prevents cones from opening and releasing seeds (Merrick et al., 2007; Smith and Mannan, 1994; Zugmeyer and Koprowski, 2009). Mt. Graham red squirrel is a subspecies that is isolated and endemic to high elevation forests $(>2,000 \mathrm{~m})$ of the Pinaleño Mountains, which are surrounded by desert and grassland, and represents the southernmost population of red squirrels (Brown, 1984; Steele, 1998). Because of geographic isolation, declining and low population numbers ( 300 individuals, Sanderson \& Koprowski 2009), and habitat destruction, Mt. Graham red squirrels were listed as federally endangered in 1987 (U.S. Fish and Wildlife Service, 1987). In addition to habitat loss, severe fire, and insect damage, a potential threat to Mt. Graham red squirrels is human disturbance from recreation, road traffic, and habitat modification associated with road improvement (Buenau and Gerber, 2004; U.S. Fish and Wildlife Service, 2011; Zugmeyer and Koprowski, 2009).

\subsection{Animal space use}

We used standard methods to trap, fit unique ear tags and affix radio collars on red squirrels, and located red squirrels during daylight hours and estimated the location of each animal via biangulation (Koprowski et al., 2008). We used radio telemetry data to estimate $95 \%$ (total) and 50\% (core) fixed kernel home ranges for individual red squirrels each season (spring: March-May, summer: June-August, fall: September-November, winter: December to January, Koprowski et al. 2008). For this study, we used home ranges from December 2008 (when airborne LiDAR data were collected) to November 2012 during which no major forest disturbance occurred. During natal dispersal, movements patterns of juvenile red squirrels are different from adults (Larsen and Boutin, 1994), so we only included adult and subadult red squirrels that have completed natal dispersal in our analyses. Home ranges estimated with $<15$ fixes were excluded. Mean number of locations per home range was 40 fixes (SE 0.60, $n=307$ ). 2.3 Linear features

We mapped low to high traffic roads with high-resolution aerial imagery obtained from the National Agriculture Imagery Program (NAIP) in 2007 (Fig. 1a). We defined road edges that were parallel to roads with a distance of $25 \mathrm{~m}$ from roads as boundaries of roadside areas (Fig 1a.). We chose $25 \mathrm{~m}$ because edge effects of roads usually decrease within the first $50 \mathrm{~m}$ of forests (Murcia, 1995). To resemble linear gaps in canopy cover created by roads in roadless areas, we used the GIS layer (25-m resolution) derived from three-dimensional LiDAR (Light Detection and Ranging) data (Mitchell et al., 2012) to map linear areas with low to high canopy 
cover: $0-25 \%(n=9), 25-50 \%(n=10), 50-75 \%(n=14)$, and $75-100 \%$ cover $(n=13)$. Mean length of linear areas was $242.4 \mathrm{~m}$ (SE 20). We considered areas with canopy cover $<50 \%$ as gaps for red squirrels on the basis of the minimum documented canopy cover at red squirrel middens (Smith and Mannan, 1994). To create random lines in forests that serve as references with similar density of roads $\left(1.93 \mathrm{~km} / \mathrm{km}^{2}\right)$, we used ArcGIS Desktop 9.3 (Environmental Systems Research Institute) to generate 20 random points and create $300-\mathrm{m}$ straight lines from each point in a randomly selected direction (Fig. 1a). We chose $300 \mathrm{~m}$ on the basis of the mean size of red squirrel 95\% fixed kernel home ranges from 2009 to 2012 (mean [SE] $=2.65$ [0.23] ha). If we consider the home range as a circle, the diameter would be about $200 \mathrm{~m}$, thus a $300 \mathrm{~m}$ segment is appropriate to match the spatial scale of red squirrel space use. We also divided roads and road edges into 300-m long sections. Mean length of canopy gaps was $167.1 \mathrm{~m}$ (SE 20). 2.4 Data analysis

2.4.1 Barrier effects of roads- traffic, edge, and gap avoidance

For each linear feature, we selected red squirrels with residential middens $<100 \mathrm{~m}$ from the linear feature and determined if red squirrels included these linear features in their total and core home ranges and used this metric as an indicator of crossing and preference for habitat adjacent to the linear features. We based $100 \mathrm{~m}$ on the size of home range and mobility of red squirrels (Koprowski et al., 2008). Depending on the location of the residential midden, a red squirrel may encounter $>1$ linear features. We used generalized linear mixed modeling (GLMM) with a logit link function and binomial error distribution to compare the probability of total and core home range including linear features with 'include' as a binary response variable (include $=$ 1 , not include $=0$ ). We included types of linear features (low to high traffic roads, road edges, linear areas with low to high canopy cover, random lines, Table 1), sex, season (spring, summer, fall, winter) and body mass (g) as fixed effects, and individual squirrels, individual linear features and seasons (16 seasons in 4 years) as random effects. Body mass was calculated as the mean of masses recorded during a season. When seasonal body mass was not available, we estimated body mass as the mean mass during the year.

\subsubsection{Predictors of crossing random lines}

To understand factors that influence animal movements in forests, we explored how environmental characteristics of random lines affect probability of crossing. For each random line, we used the Geospatial Modelling Environment (GME, Beyer 2012) to calculate mean, maximum and minimum value of slope, aspect (degree to north), distance to recent fire boundaries (Clark Peak Fire in 1997 and Nuttall Complex Fire in 2004, m), distance to the nearest road $(\mathrm{m})$, and measures of forest structure extracted from LiDAR data, including mean tree height $(\mathrm{m})$, standard deviation of tree height $(\mathrm{m})$, live and total basal area $\left(\mathrm{m}^{2} / \mathrm{ha}\right)$, and canopy cover (\%). To quantify rate of crossing random lines, we established a buffer of $100 \mathrm{~m}$ around each random line and recorded number of squirrel locations within the buffer on both sides of the line (Fig. 1b). We referred to locations on the same side of the line with the residential midden as fix-proximate, and locations on the opposite side as fix-distal (Fig. 1b). We used GLMM with a logit link function and binomial error distribution to quantify probability of crossing with fix-distal as cross and fix-proximate as not cross. We treated individual squirrels, random lines and seasons as random effects and the remaining variables as fixed effects. When collinearity occurred between variables $(r>0.7)$, we selected variables with lower $p$ value.

2.4.3 Predictors of crossing roads

To identify important features that may improve road permeability, we investigated how roadside environment and road characteristics affect rate of road crossing. Road characteristics 
included road width (m), road clearance (distance between forest boundaries, $\mathrm{m}$ ), and traffic (low, medium, high). We measured road width and road clearance every $50 \mathrm{~m}$ and calculated the mean, maximum and minimum value for each 300-m long road section. Because the presence of red squirrels on the other side of roads may further affect decisions to cross roads (either negatively, such as avoiding conspecifics, or positively such as locating mates), we created a 100-m buffer surrounding road sections, and recorded presence or absence of a red squirrel on the opposite side of the road and number of squirrels of the same and different sex from the focal squirrel on both sides of the road, referred to as presence of squirrel-distal, presence or number of matesproximate or distal, presence or number of conspecifics-proximate or distal. Due to a high proportion of zeros for fixes-distal, we used zero-inflated generalized liner models (ZIGLMM) with a log link function and Poisson error distribution to quantify frequency of crossing with fixdistal as cross and fix-proximate as not cross. We included total number of fix (natural log transformed) as an offset in the model. We included individual squirrels, random lines and seasons as random effects and the remaining variables as fixed effects.

We ran GLMM with the lme4 (Linear mixed-effects models using Eigen and S4, Bates et al., 2013) package and ZIGLMM with the glmmADMB package (Generalized Linear Mixed Models using AD Model Builder, Skaug et al., 2013) in R (version 3.1.0 -"Spring Dance", R Development Core Team 2014). We standardized all continuous variables to mean $=0$ and standard deviation $=1$ to improve numerical convergence.

\section{Results}

We included 307 home ranges that estimated each season for 77 squirrels (39 male, 39 female) in our analyses. No mortality of red squirrels duo to wildlife-vehicle collision was detected. Middens were present on both sides of roads along $92.9 \%$ of road sections $(n=14)$, and $64.4 \%$ of middens censused $(n=101)$ were occupied by red squirrels at least one season from 2008 to 2012. Mean distance from middens to roads was $62.2 \mathrm{~m}(\mathrm{SE} 4.4, n=38)$ and to random lines was $44.8 \mathrm{~m}\left(\mathrm{SE} 3.4, n=64, t_{100}=-3.12, p=0.002\right)$.

\subsection{Barrier effects of roads - traffic, edge, and gap avoidance}

Roads were barriers for red squirrels. Odds of red squirrels crossing random lines were 4.8 times of odds of crossing roads, and odds of including random lines in core home ranges was 12.5 times of odds of including roads (Table 1). Increased traffic on roads did not decrease probability of crossing (Fig. 2). Probability of road crossing was lowest on low traffic roads, followed by high traffic roads and medium traffic roads (Fig. 2). The odds of red squirrel core home ranges including roads were similar among low to high traffic roads (Table 1). Red squirrels crossed roads more often during the period when roads were open to traffic than road closure. The percentage of total home ranges that included roads decreased by $84.9 \%$ from $63.9 \%(n=36)$ in summer when the road was open to $9.7 \%(n=31)$ in winter when road was closed, whereas we observed only a $20.7 \%$ decrease in percentage of total home ranges included random lines, from $81.3 \%(n=64)$ in summer to $64.4 \%(n=59)$ in winter. Red squirrels did not avoid road edges as near as $25 \mathrm{~m}$ from roads. Odds of red squirrel including road edges in their total and core home ranges were 3.3 times and 1.1 times respectively odds of including random lines (Table 1). In contrast, red squirrels avoided gaps (canopy cover $<50 \%$ ). Probability of crossing linear areas with canopy cover $>50 \%(0.7$, Fig. 3$)$ was higher than probability of crossing gaps (0.2, Fig. 3). Odds of red squirrels crossing random lines was 5.1 times that of crossing gaps and odds of including random lines in core home ranges was 4.6 times of odds of including gaps (Table 1). 


\subsection{Predictors of crossing random lines}

Probability of crossing decreased as distance from middens to linear features increased, and increased as body mass increased (Table 2). Rate of crossing increased as the maximum canopy cover recorded along random lines increased, and was not affected by distance from roads. Each percentage increase in maximum canopy cover of random lines increased the odds of crossing by $33 \%$ (Table 2 ).

\subsection{Predictors of crossing roads}

Forty-three red squirrels occupied middens $<100 \mathrm{~m}$ from roads (23 male, 20 female), and $67.4 \%$ of individuals had home ranges that overlapped roads in at least one season from 2008 to 2012, which means $32.6 \%$ of individuals were never detected to cross roads in 4 years.

Reproductive activities were the most important factors in predicting road crossings. Rate of road crossing by red squirrels was 2.1 times larger in the mating season and increased number of potential mates on the proximate side of roads increased rate of road crossing (Table 3 ). Presence of potential mates on the opposite side of roads increased the rate of crossing by 3.7 times. Rate of crossing also increased as the maximum standard deviation of tree height recorded along roads increased. Each meter increase in maximum standard deviation of tree height increased the rate of crossing by 2.7 times (Table 3). Effect of traffic volume was not significant after accounting for road and environmental characteristics and squirrel activity (Table 3).

\section{Discussion}

\subsection{Forest roads serve as barriers}

By integrating long-term demographic and telemetry data with remotely sensed environmental characteristics, our study directly assesses effects of roads, traffic intensity, and distance to roads simultaneously on space use and movements of small mammals. In addition, we show how environment, seasonal variation in animal activities, and social interactions affect probability of road crossing. We demonstrate that even a narrow $(<10 \mathrm{~m})$, gravel forest road with low traffic volume ( $<10$ vehicles/day) can restrict animal space use and inhibit movements. Furthermore, we conclude that gap avoidance plays an important role in inhibition of road crossings by forest dependent species. An alternative explanation for the low probability of road crossing is lack of habitat on the opposite side of the road (Riley et al., 2006). However, given that red squirrel territories were present on both sides of roads in our study area, we conclude this was unlikely. The avoidance of roads by red squirrels was previously suggested through live trapping studies, as red squirrels are scarce at culverts despite being the most abundant species in the adjacent forest (Clevenger et al., 2001). Small mammals are known to avoid crossing narrow, unpaved roads (Oxley et al., 1974; Swihart and Slade, 1984). Our research provides insight on the causes and mechanisms contributing to barrier effects of roads and helps anticipate how forest obligates respond to anthropogenic disturbance in fragmented landscapes (Burnett, 1992; Koprowski, 2005; Laurance et al., 2009).

4.2 Traffic volume and road edges have little effect on road crossing and space use Increasing traffic intensity can reduce success of road crossing (Gagnon et al., 2007; Richardson et al., 1997). However, effect of traffic on animal movements is difficult to disentangle from the influence of road characteristics, because of temporal variation in traffic volume and positive correlation with road width (Goosem, 2002; McGregor et al., 2008). We demonstrated that low traffic volume ( $<100$ vehicles/day) has little effect on probability of road crossing after accounting for effects of road and environmental characteristics. Previous studies suggest that traffic volume does not influence rate of road crossing by small mammals, and increasing traffic intensity up to 15,000 vehicles/day does not decrease the success of return by 
small rodents after translocation (Ford and Lenore, 2008; Goosem, 2002; McGregor et al., 2008). Yet, animals may cross high traffic roads during low traffic periods, and result in animal space use that appears similar between high and low traffic roads (McGregor et al., 2008). Besides rate of road crossing, traffic may affect animal movements patterns near roads, including distance from roads, travel speed, and tortuosity. Fine scale records of traffic and animal movements are required to further understand effects of traffic intensity on barrier effects of roads.

Road edges, differ from natural edges or edges produced by clearcuts in their linear configuration, length, and spatially extensive effects driven by associated anthropogenic disturbance (Forman and Alexander, 1998; Saunders et al., 2002). Consequently, forest fragmentation and edges introduced by roads are widely distributed, tend to exist for long periods of time and are exacerbated by frequent disturbance (Coffin, 2007; Pohlman et al., 2007; Reed et al., 1996). We did not find evidence that road edges affect animal movements and space use, since individuals lived at roadside areas did not avoid approaching roads, and distance from linear features to roads did not affect probability of crossing. Roads affect animal population density and community structure, and the influences can extend to several kilometers from the road (Benítez-López et al., 2010; Fuentes-Montemayor et al., 2009). We documented effects of traffic volume and road edges on movements and space use of red squirrels, but effects of traffic disturbance and roadside environment on distribution and abundance remain unknown. Environmental changes in forest structure, microclimate, and forest dynamics near road edges, including lower forest density, increased solar radiation, wind velocity and light availability, extreme temperature (Goosem, 2007; Murcia, 1995), may influence animal populations and distribution, especially for species like red squirrels whose habitat is limited to forest interior and are sensitive to forest fragmentation (Koprowski, 2005; Laurance et al., 2009).

4.3 Gaps in canopy cover inhibit animal movements

Animals tend to recognize linear features as territory boundaries, which may restrict an individual's movements to one side of a road and result in changes in space use (Burnett, 1992; Trombulak and Frissell, 2000). Road clearance, the distance an animal has to move between forest margins to cross the roadways (Oxley et al., 1974), has been suggested as the main factor that causes inhibition of road crossing by small mammals. We propose that the avoidance of gaps in cover created by roads is the primary reason. We have 3 lines of evidence that support this conclusion: (1) red squirrels were less likely to cross gaps with $<50 \%$ canopy cover compared to random lines in forests; (2) probability of crossing random lines in forests was affected positively by canopy cover; (3) probability of road crossing increased with increased standard deviation of tree height that was positively correlated with canopy cover.

Forest specialists like tree squirrels often avoid entering gaps with low canopy or understory cover, and rarely cross roads spontaneously, and therefore are especially vulnerable to barrier effects of roads (Clevenger et al., 2001; Laurance et al., 2009; Oxley et al., 1974). Red squirrels strongly avoided clearcuts, and only cross forest gaps if a detour through forest is relatively energy inefficient (Bakker and Van Vuren, 2004). However, alternate routes of crossing roads are usually not available. Predation risk is higher in more open microhabitats (Barbosa and Castellanos, 2005). Tree squirrels rely on canopy cover to provide shelter and use arboreal escape routes when encountering aerial or ground predators (Temple, 1987). Red squirrels travel more slowly through open areas, likely due to high predation risk (Bakker and Van Vuren, 2004). On Mt. Graham, the major source of mortality in red squirrels is avian predation (U.S. Fish and Wildlife Service, 2011), and mortality is higher in more open forests (Zugmeyer and Koprowski, 2009). Open areas created by roads may increase risk of predation or 
mortality caused by vehicle collisions. Besides greater predation risk, lack of connectivity in canopy over roads also impedes arboreal movements. Strong influence of standard deviation of tree height on road crossing suggests that physical structure of forest is important. Forests with higher variation in tree height may provide animals cover and assist arboreal movements when animals descend to ground to cross roads. The northern flying squirrels (Glaucomys sabrinus) rely on forest structure in old-growth forests, including high canopy and relatively open under and mid story layers to provide launch point and space for glide (Scheibe et al., 2006). The Siberian flying squirrels (Pteromys volans) cross completely open areas only when gaps can be crossed in a single glide (Selonen and Hanski, 2003). A similar pattern also occurs in other arboreal species such as squirrel gliders (Petaurus norfolcensis, van der Ree et al. 2010) and ringtail possum (Hemibelideus lemuroides, Wilson et al. 2007).

4.4 Mating activity increases road crossing

Seasonal variation in activity affects probability of road crossing (Fahrig and Rytwinski, 2009). For instance, moose (Alces alces) cross roads more frequently in summer with increased movements range (Beyer et al., 2013). Some species seldom crossed roads during daily movements, but appear to be more likely to cross roads under situations of high motivation, for example in the breeding season (Steen et al., 2006), after translocation (Clark et al., 2001) or during dispersal (deMaynadier and Hunter, 2000). Male mammals often increase their home range in mating season to search for potential mates (Clark et al., 2010; Edelman and Koprowski, 2006; Koprowski et al., 2008). The positive relationship between presence of a potential mate on both sides of roads and rate of road crossings also suggests the influential role of mate searching behavior on crossing events. Avoidance of conspecifics and territorial defense by residential red squirrels could lead to reduced rate of road crossing (Bakker and Van Vuren, 2004). Although we did not detect seasonal variation in effects of presence of red squirrels on the opposite side of roads, avoidance of conspecifics may contribute to the observed difference of probability of road crossing between mating and non-mating season. Our findings suggest that the permeability of a barrier changes with motivation and increases with the availability of receptive potential mates. However, even during mating season, probability of road crossing was lower than crossing random lines. About $75 \%$ of red squirrel home ranges included random lines, whereas $53 \%$ of home ranges included roads. Presence of roads impairs male snakes' ability of locating mates (Shine et al., 2004). Gene flow between populations bisected by roads is reduced, likely due to fewer mating between individuals separated by roads than individuals at one side of roads (Clark et al., 2010; Riley et al., 2006). We show forest roads affect animal daily movements in home range, and seasonal space use. As a result, forest roads can have negative effects on population through impede reproductive activity, dispersal, and survivorship. Although increased distance between patchy habitats and long dispersal distance does not necessarily decrease success of settlement and survivorship (Larsen and Boutin, 1994; Selonen and Hanski, 2012), this might not be the case when animals need to cross roads to settle as risk of road mortality may be too high to cross and alternate routes may not be available.

\section{Conservation Implications}

The ecological and genetic consequences of inhibition of movements and population isolation can be serious, particularly in limited habitat, especially for populations of species at the edge of their distribution range like Mt. Graham red squirrels (Fahrig and Paloheimo, 1988; Fitak et al., 2013; Leonard and Koprowski, 2009). Persistence of forest obligates in isolated fragments depends on their physiological and locomotor ability to cross gaps and the connectivity of fragments (Fahrig, 2007; Lees and Peres, 2009). Although forest roads did not 
completely inhibit squirrel movements, the barrier effects of roads could be magnified for individuals residing further from roads, if red squirrels that occupied middens near roads represent individuals with high tolerance to road impacts(Anderson and Boutin, 2002; Boon et al., 2007). Moreover, forest roads can have long-term impacts as about one-third of the red squirrels that were resident near roads were never observed to cross roads in 4 years. Given that Mt. Graham red squirrels have already suffered from habitat loss and destruction associated with severe fire, insect damage, and development (Buenau and Gerber, 2004; U.S. Fish and Wildlife Service, 2011; Zugmeyer and Koprowski, 2009), effective mitigation of barrier effects of roads appears prudent.

The finding that maximum value of canopy cover and standard deviation of tree height influences crossing decisions of red squirrels has important conservation implications. This suggests that road permeability can be improved by maintaining canopy cover along short sections of roads. Although increased canopy closure along the road may facilitate road crossing, it may also increase road mortality (van der Ree et al., 2010). To minimize barrier effects of roads while simultaneously reducing road mortality, a variety of wildlife passages have been designed and installed to facilitate movements of wildlife and restore connectivity(Taylor and Goldingay, 2010). Canopy bridges or rope bridges successfully restored animal movements near roads and improved connectivity for several arboreal species (Laurance et al., 2009; Soanes et al., 2013), and can be another mitigation of road impacts on red squirrels.

Forest roads are thought to have reduced impacts on wildlife because roads are often narrow, unpaved, and lightly traveled. However, ecological effects are substantial due to wide distribution of forest roads and their facilitation of the introduction of human disturbance to remote areas (Coghlan and Sowa, 1998; Forman and Alexander, 1998; Forman et al., 2003). Several studies have demonstrated that even narrow roads $<10$-m wide with low traffic intensity are barriers for many species (Forman and Alexander, 1998; Swihart and Slade, 1984). Not only roads but also open clearings like powerline corridors can restrict the movements of small mammals in forests (Goosem and Marsh, 1997). As we show gaps in canopy strongly inhibits animal movements, forest management such as thinning operations and infrastructure development that open forest canopy can increase barrier effects and level of fragmentation, and should be implemented with caution. Human induced habitat fragmentation is one of the major causes for the decline of biodiversity (Fahrig, 2003). In the U.S., forest road network has expanded to $>600,000 \mathrm{~km}$ and traffic intensity has grown 10 times since $1950 \mathrm{~s}$ and reached to 1.7 million vehicles/day in 1998 (Coghlan and Sowa, 1998). Forest ecosystems worldwide have been excessively fragmented through human activities, and primary forests have decreased by $>40$ million ha since 2000 , yet the degree of fragmentation is exacerbated by continuously increasing demand for outdoor recreational activities and development as well as catastrophic events driven by climate change (Allen et al., 2010; Food and Agriculture Organization of the United Nations, 2010). Thus, forest species are facing challenging landscapes with more fragmented and disturbed habitats. To maintain landscape connectivity, large areas of healthy forests as well as connectivity among forested patches are of critical importance.

\section{Acknowledgments}

We thank the University of Arizona, Arizona Agriculture Experiment Station, and T\&E Incorporated's Grants for Conservation Research for providing funding, the University of Arizona Statistics Consulting Lab in assisting with data analyses, and R. Gimblett, C. Schwalbe, R. Steidl for review and feedback on study design. 


\section{References}

Allen, C.D., Macalady, A.K., Chenchouni, H., Bachelet, D., McDowell, N., Vennetier, M., Kitzberger, T., Rigling, A., Breshears, D.D., Hogg, E.H. (Ted), Gonzalez, P., Fensham, R., Zhang, Z., Castro, J., Demidova, N., Lim, J.-H., Allard, G., Running, S.W., Semerci, A., Cobb, N., 2010. A global overview of drought and heat-induced tree mortality reveals emerging climate change risks for forests. For. Ecol. Manage. 259, 660-684. doi:10.1016/j.foreco.2009.09.001

Anderson, E.M., Boutin, S., 2002. Edge effects on survival and behaviour of juvenile red squirrels (Tamiasciurus hudsonicus). Can. J. Zool. 80, 1038-1046. doi:10.1139/z02-087

Bakker, V.J., Van Vuren, D.H., 2004. Gap-crossing decisions by the red squirrel, a forestdependent small mammal. Conserv. Biol. 18, 689-697. doi:10.1111/j.15231739.2004.00149.x

Barber, J.R., Crooks, K.R., Fristrup, K.M., 2010. The costs of chronic noise exposure for terrestrial organisms. Trends Ecol. Evol. 25, 180-189. doi:10.1016/j.tree.2009.08.002

Barbosa, P., Castellanos, I. (Eds.), 2005. Ecology of predator-prey interactions. Oxford University Press. Oxford. UK.

Bates, D., M., Maechler, B.B., Walker, S., 2013. lme4: Linear mixed-effects models using Eigen and S4.

Benítez-López, A., Alkemade, R., Verweij, P.A., 2010. The impacts of roads and other infrastructure on mammal and bird populations: a meta-analysis. Biol. Conserv. 143, 13071316. doi:10.1016/j.biocon.2010.02.009

Beyer, H.L., 2012. Geospatial Modelling Environment.

Beyer, H.L., Ung, R., Murray, D.L., Fortin, M.J., 2013. Functional responses, seasonal variation and thresholds in behavioural responses of moose to road density. J. Appl. Ecol. 50, 286294. doi:10.1111/1365-2664.12042

Bhattacharya, M., Primack, R.B., Gerwein, J., 2003. Are roads and railroads barriers to bumblebee movement in a temperate suburban conservation area? Biol. Conserv. 109, $37-$ 45. doi:10.1016/s0006-3207(02)00130-1

Bissonette, J.A., Rosa, S.A., 2009. Road zone effects in small-mammal communities. Ecol. Soc. $14,27$.

Boon, A.K., Réale, D., Boutin, S., 2007. The interaction between personality, offspring fitness and food abundance in North American red squirrels. Ecol. Lett. 10, 1094-104. doi:10.1111/j.1461-0248.2007.01106.x

Brown, D.E., 1984. Arizona's tree squirrels. Arizona Game and Fish Department, Phoenix, Arizona, USA.

Buenau, K.E., Gerber, L.R., 2004. Developing recovery and monitoring strategies for the endemic Mount Graham red squirrels (Tamiasciurus hudsonicus grahamensis) in Arizona. Anim. Conserv. 7, 17-22. doi:10.1017/S1367943003001124

Burnett, S.E., 1992. Effects of a rain-forest road on movements of small mammals-mechanisms and implications. Wildl. Res. 19, 95-104.

Chen, H., Koprowski, J.L., 2013. Effects of roads on wildlife in Arizona: how far have we traveled?, in: Merging Science and Management in a Rapidly Changing World: Biodiversity and Management of the Madrean Archipelago III and 7th Conference on Research and Resource Management in the Southwestern Deserts. Proceedings. RMRS-P-67. Rocky Mountain Research Station, U.S. Forest Service, Fort Collins, Colorado, USA., pp. 434-438. Clark, B.K., Clark, B.S., Johnson, L.A., Haynie, M.T., 2001. Influence of roads on movements 
of small mammals. Southwest. Nat. 46, 338-344.

Clark, R.W., Brown, W.S., Stechert, R., Zamudio, K.R., 2010. Roads, interrupted dispersal, and genetic diversity in timber rattlesnakes. Conserv. Biol. 24, 1059-69. doi:10.1111/j.15231739.2009.01439.x

Clevenger, A.P., Chruszcz, B., Gunson, K., 2001. Drainage culverts as habitat linkages and factors affecting passage by mammals. J. Appl. Ecol. 38, 1340-1349. doi:10.1046/j.00218901.2001.00678.x

Coffin, A.W., 2007. From roadkill to road ecology: a review of the ecological effects of roads. J. Transp. Geogr. 15, 396-406. doi:10.1016/j.jtrangeo.2006.11.006

Coghlan, G., Sowa, R., 1998. National forest road system and use. USDA Forest Service Engineering Staff: Washington D.C. (Draft 1/30/98).

Czech, B., Krausman, P.R., 1997. Distribution and causation of species endangerment in the United States. Science. 277, 1116-1117. doi:10.1126/science.277.5329.1116

deMaynadier, P.G., Hunter, M.L., 2000. Road effects on amphibian movements in a forested landscape. Nat. Areas J. 20, 56-65.

Edelman, A.J., Koprowski, J.L., 2006. Seasonal changes in home ranges of Abert's squirrels: impact of mating season. Can. J. Zool. 84, 404-411. doi:10.1139/z06-009

Fahrig, L., 2007. Non-optimal animal movement in human-altered landscapes. Funct. Ecol. 21, 1003-1015. doi:10.1111/j.1365-2435.2007.01326.x

Fahrig, L., 2003. Effects of habitat fragmentation on biodiversity. Annu. Rev. Ecol. Evol. Syst. 34, 487-515. doi:10.1146/annurev.ecolsys.34.011802.132419

Fahrig, L., Paloheimo, J., 1988. Determinants of local population size in patchy habitats. Theor. Popul. Biol. 34, 194-213.

Fahrig, L., Rytwinski, T., 2009. Effects of roads on animal abundance: an empirical review and synthesis. Ecol. Soc. 14, 21.

Fitak, R.R., Koprowski, J.L., Culver, M., 2013. Severe reduction in genetic variation in a montane isolate: the endangered Mount Graham red squirrel (Tamiasciurus hudsonicus grahamensis). Conserv. Genet. 14, 1233-1241. doi:10.1007/s10592-013-0511-x

Food and Agriculture Organization of the United Nations, 2010. Global forest resources assessment 2010 - Main report. Forestry Paper 163, FAO, Forestry, Rome.

Ford, A.T., Lenore, F., 2008. Movement patterns of eastern chipmunks (Tamias striatus) near roads. J. Mammal. 89, 895-903.

Forman, R.T.T., Alexander, L.E., 1998. Roads and their major ecological effects. Annu. Rev. Ecol. Syst. 29, 207-231.

Forman, R.T.T., Sperling, D., Bissonette, J.A., Clevenger, A.P., Cutshall, C.D., Dale, V.H., Fahrig, L., France, R.L., Goldman, C.R., Heanue, K., Jones, J., Swanson, F., Turrentine, T., Winter, T.C., 2003. Road ecology: science and solutions, 2nd ed. Island Press, Washington, D.C., USA.

Frankham, R., 1996. Relationship of genetic variation to population size in wildlife. Conserv. Biol. 10, 1500-1508. doi:10.1046/j.1523-1739.1996.10061500.x

Fuentes-Montemayor, E., Cuarón, A.D., Vázquez-Domínguez, E., Benítez-Malvido, J., Valenzuela-Galván, D., Andresen, E., 2009. Living on the edge: roads and edge effects on small mammal populations. J. Anim. Ecol. 78, 857-865. doi:10.1111/j.13652656.2009.01551.x

Gagnon, J.W., Theimer, T.C., Dodd, N.L., Boe, S., Schweinsburg, R.E., 2007. Traffic volume alters elk distribution and highway crossings in Arizona. J. Wildl. Manage. 71, 2318-2323. 
doi:10.2193/2006-224

Goosem, M., 2007. Fragmentation impacts caused by roads through rainforests. Curr. Sci. 93, $1587-1595$.

Goosem, M., 2002. Effects of tropical rainforest roads on small mammals: fragmentation, edge effects and traffic disturbance. Wildl. Res. 29, 277-289. doi:10.1071/wr01058

Goosem, M., 2000. Effects of tropical rainforest roads on small mammals: edge changes in community composition. Wildl. Res. 27, 151-163.

Goosem, M., Marsh, H., 1997. Fragmentation of a small-mammal community by a powerline corridor through tropical rainforest. Wildl. Res. 24, 613-629. doi:10.1071/wr96063

Greenberg, R., 1989. Neophobia, aversion to open space, and ecological plasticity in Song and Swamp sparrows. Can. J. Zool. 67, 1194-1199. doi:10.1139/z89-172

Gurnell, J., 1987. The natural history of squirrels. Christopher Helm, London, Great Britain. Gurnell, J., Pepper, H., 1994. Red squirrel conservation field study methods. United Kingdom Forestry Commission Research Information Note 191 Edinburgh: Forestry Commission.

Hanski, I., Gilpin, M., 1991. Metapopulation dynamics: brief history and conceptual domain. Biol. J. Linn. Soc. 42, 3-16. doi:10.1111/j.1095-8312.1991.tb00548.x

Jaeger, J.A.G., Bowman, J., Brennan, J., Fahrig, L., Bert, D., Bouchard, J., Charbonneau, N., Frank, K., Gruber, B., von Toschanowitz, K.T., 2005. Predicting when animal populations are at risk from roads: an interactive model of road avoidance behavior. Ecol. Modell. 185, 329-348. doi:10.1016/j.ecolmodel.2004.12.015

Koprowski, J.L., 2005. The response of tree squirrels to fragmentation: a review and synthesis. Anim. Conserv. 8, 369-376. doi:10.1017/S1367943005002416

Koprowski, J.L., King, S.R.B., Merrick, M.J., 2008. Expanded home ranges in a peripheral population: space use by endangered Mt. Graham red squirrels. Endanger. Species Res. 4, 227-232. doi:10.3354/esr00026

Larsen, K.W., Boutin, S., 1994. Movements, survival, and settlement of red squirrel (Tamiasciurus hudsonicus) offspring. Ecology 75, 214-223. doi:10.2307/1939395

Laurance, S.G.W., Stouffer, P.C., Laurance, W.E., 2004. Effects of road clearings on movement patterns of understory rainforest birds in central Amazonia. Conserv. Biol. 18, 1099-1109.

Laurance, W.F., Goosem, M., Laurance, S.G.W., 2009. Impacts of roads and linear clearings on tropical forests. Trends Ecol. Evol. 24, 659-669. doi:10.1016/j.tree.2009.06.009

Lees, A.C., Peres, C.A., 2009. Gap-crossing movements predict species occupancy in Amazonian forest fragments. Oikos 118, 280-290. doi:10.1111/j.1600-0706.2008.16842.x

Leonard, K., Koprowski, J., 2009. A comparison of habitat use and demography of red squirrels at the southern edge of their range. Am. Midl. Nat. 162, 125-138.

Marsh, D.M., Milam, G.S., Gorham, N.R., Beckman, N.G., 2005. Forest roads as partial barriers to terrestrial salamander movement. Conserv. Biol. 19, 2004-2008. doi:10.1111/j.15231739.2005.00238.x

McDonald, W.R., St Clair, C.C., 2004. The effects of artificial and natural barriers on the movement of small mammals in Banff National Park, Canada. Oikos 105, 397-407.

McGregor, R.L., Bender, D.J., Fahrig, L., 2008. Do small mammals avoid roads because of the traffic? J. Appl. Ecol. 45, 117-123. doi:10.1111/j.1365-2664.2007.01403.x

Merrick, M.J., Bertelsen, S.R., Koprowski, J.L., 2007. Characteristics of Mount Graham red squirrel nest sites in a mixed conifer forest. J. Wildl. Manage. 71, 1958-1963. doi:10.2193/2006-260

Mitchell, B., Walterman, M., Mellin, T., Wilcox, C., Lynch, A.M., Anhold, J., Falk, D.A., 
Koprowski, J., Laes, D., Evans, D., Fisk., H., 2012. Mapping vegetation structure in the Pinaleño Mountains using LiDAR-phase 3: forest inventory modeling. RSAC-10007-RPT1. Remote Sensing Applications Center, U.S. Forest Service, Salt Lake City, Utah, USA.

Murcia, C., 1995. Edge effects in fragmented forests: implications for conservation. Trends Ecol. Evol. 10, 58-62. doi:10.1016/s0169-5347(00)88977-6

Oxley, D.J., Fenton, M.B., Carmody, G.R., 1974. Effects of roads on population of small mammals. J. Appl. Ecol. 11, 51-59.

Pohlman, C.L., Turton, S.M., Goosem, M., 2007. Edge effects of linear canopy openings on tropical rain forest understory microclimate. Biotropica 39, 62-71. doi:10.1111/j.17447429.2006.00238.x

Reed, R., Johnson-Barnard, J., Baker, W., 1996. Contribution of roads to forest fragmentation in the Rocky Mountains. Conserv. Biol. 10, 1098-1106. doi:10.1046/j.15231739.1996.10041098.x

Richardson, J.H., Shore, R.F., Treweek, J.R., Larkin, S.B.C., 1997. Are major roads a barrier to small mammals? J. Zool. 243, 840-846.

Riley, S.P.D., Pollinger, J.P., Sauvajot, R.M., York, E.C., Bromley, C., Fuller, T.K., Wayne, R.K., 2006. A southern California freeway is a physical and social barrier to gene flow in carnivores. Mol. Ecol. 15, 1733-1741. doi:10.1111/j.1365-294X.2006.02907.X

Roedenbeck, I.A., Fahrig, L., Findlay, C.S., Houlahan, J.E., Jaeger, J.A.G., Klar, N., KramerSchadt, S., van der Grift, E.A., 2007. The Rauischholzhausen agenda for road ecology. Ecol. Soc. 12, 11.

Rytwinski, T., Fahrig, L., 2012. Do species life history traits explain population responses to roads? a meta-analysis. Biol. Conserv. 147, 87-98. doi:10.1016/j.biocon.2011.11.023

Sanderson, H.R., Koprowski, J.L., 2009. The last refuge of the Mt. Graham red squirrel. University of Arizona Press, Tucson, Arizona, USA.

Saunders, S.C., Mislivets, M.R., Chen, J., Cleland, D.T., 2002. Effects of roads on landscape structure within nested ecological units of the Northern Great Lakes Region, USA. Biol. Conserv. 103, 209-225. doi:10.1016/S0006-3207(01)00130-6

Scheibe, J.S., Smith, W.P., Bassham, J., Magness, D., 2006. Locomotor performance and cost of transport in the northern flying squirrel Glaucomys sabrinus. Acta Theriol. (Warsz). 51, 169-178. doi:10.1007/BF03192668

Selonen, V., Hanski, I.K., 2012. Dispersing Siberian flying squirrels (Pteromys volans) locate preferred habitats in fragmented landscapes. Can. J. Zool. 90, 885-892. doi:10.1139/z2012058

Selonen, V., Hanski, I.K., 2003. Movements of the flying squirrel Pteromys uolans in corridors and in matrix habitat. Ecography (Cop.). 26, 641-651.

Shepard, D.B., Kuhns, A.R., Dreslik, M.J., Phillips, C.A., 2008. Roads as barriers to animal movement in fragmented landscapes. Anim. Conserv. 11, 288-296. doi:10.1111/j.14691795.2008.00183.x

Shine, R., Lemaster, M., Wall, M., Langkilde, T., Mason, R., 2004. Why did the snake cross the road? Effects of roads on movement and location of mates by garter snakes (Thamnophis sirtalis parietalis). Ecol. Soc. 9.

Skaug, H., Fournier, D., Nielsen, A., Magnusson, A., Bolker, B., 2013. Generalized linear mixed models using AD Model Builder.

Smith, A.A., Mannan, R.W., 1994. Distinguishing characteristics of Mount Graham red squirrel midden sites. J. Wildl. Manage. 58, 437-445. 
Soanes, K., Lobo, M.C., Vesk, P.A., McCarthy, M.A., Moore, J.L., van der Ree, R., 2013. Movement re-established but not restored: inferring the effectiveness of road-crossing mitigation for a gliding mammal by monitoring use. Biol. Conserv. 159, 434-441. doi:10.1016/j.biocon.2012.10.016

Steele, M.A., 1998. Tamiasciurus hudsonicus. Mamm. Species 586, 1-9.

Steen, D.A., Aresco, M.J., Beilke, S.G., Compton, B.W., Condon, E.P., Dodd, C.K., Forrester, H., Gibbons, J.W., Greene, J.L., Johnson, G., Langen, T.A., Oldham, M.J., Oxier, D.N., Saumure, R.A., Schueler, F.W., Sleeman, J.M., Smith, L.L., Tucker, J.K., Gibbs, J.P., 2006. Relative vulnerability of female turtles to road mortality. Anim. Conserv. 9, 269-273. doi:10.1111/j.1469-1795.2006.00032.x

Strasburg, J.L., 2006. Conservation biology - roads and genetic connectivity. Nature 440, 875876. doi:10.1038/440875a

Swihart, R.K., Slade, N.A., 1984. Road crossing in Sigmodon hispidus and Microtus ochrogaster. J. Mammal. 65, 357-360.

Taylor, B.D., Goldingay, R.L., 2010. Roads and wildlife: impacts, mitigation and implications for wildlife management in Australia. Wildl. Res. 37, 320-331. doi:10.1071/wr09171

Temple, S.A., 1987. Do predators always capture substandard individuals disproportionately from prey populations? Ecology 68, 669-674. doi:10.2307/1938472

Trombulak, S.C., Frissell, C.A., 2000. Review of ecological effects of roads on terrestrial and aquatic communities. Conserv. Biol. 14, 18-30.

U.S. Fish and Wildlife Service, 2011. Draft recovery plan for the Mount Graham red squirrel (Tamiasciurus hudsonicus grahamensis), First Revision. U.S. Fish and Wildlife Service, Southwest Region, Albuquerque, New Mexico, USA.

U.S. Fish and Wildlife Service, 1987. Endangered and threatened wildlife and plants; determination of endangered status for the Mount Graham red squirrel. Fed. Regist. 52, 20994-20999.

van der Ree, R., Cesarini, S., Sunnucks, P., Moore, J.L., Taylor, A., 2010. Large gaps in canopy reduce road crossing by a gliding mammal. Ecol. Soc. 15, 35. doi:35

Wilson, R.F., Marsh, H., Winter, J., 2007. Importance of canopy connectivity for home range and movements of the rainforest arboreal ringtail possum (Hemibelideus lemuroides). Wildl. Res. 34, 177-184. doi:10.1071/wr06114

Zugmeyer, C.A., Koprowski, J.L., 2009. Severely insect-damaged forest: a temporary trap for red squirrels? For. Ecol. Manage. 257, 464-470. doi:10.1016/j.foreco.2008.09.020 


\section{Figure Legends:}

632 Figure 1. Illustration of linear features on Mt. Graham, Arizona. (a) Location of roads, road 633 edges and random lines. SW: Arizona State Highway 366, AC: access road, BC: Bible Camp 634 Road, SO: Soldier Trail. (b) Illustration of midden of Mt. Graham red squirrels (Tamiasciurus 635 hudsonicus grahamensis), 100-m buffer surrounding a road section, and examples of red 636 squirrels locations on the proximal (fix-proximal) and distal side of the road (fix-distal).

637 Figure 2. Probability of 95\% (total) and $50 \%$ (core) fixed kernel home ranges of Mt. Graham red 638 squirrels (Tamiasciurus hudsonicus grahamensis) that include linear features: low $(<10$

639 vehicles/day), medium (20-40 vehicles/day) and high (50-100 vehicles/day) traffic roads, road 640 edges, and random lines in a forest serve as references.

641 Figure 3.

642 Probability of 95\% (total) and $50 \%$ (core) fixed kernel home ranges of Mt. Graham red squirrels 643 (Tamiasciurus hudsonicus grahamensis) that include linear areas with low to high canopy cover. 
644 Table 1. Estimated coefficients of generalized linear mixed models for probability of $95 \%$ and 50

$645 \%$ fixed kernel home ranges of Mt. Graham red squirrels (Tamiasciurus hudsonicus grahamensis) 646 including linear features, 2008-2012, Mt. Graham, Arizona, USA

\begin{tabular}{lcccccc}
\hline & \multicolumn{3}{c}{$95 \%$ Kernel } & \multicolumn{3}{c}{$50 \%$ Kernel } \\
\hline Variables & Estimate & SE & $P$ & Estimate & SE & $P$ \\
\hline Linear features & & & & & & \\
$\quad$ Random line & 0.29 & 0.52 & 0.56 & -1.41 & 0.51 & 0.005 \\
Low traffic road & -1.99 & 0.94 & 0.04 & -3.71 & 0.96 & $<0.001$ \\
Medium traffic road & 0.19 & 0.97 & 0.85 & -2.90 & 1.16 & 0.01 \\
High traffic road & -1.35 & 0.79 & 0.09 & -4.10 & 0.91 & $<0.001$ \\
Road edges & 1.47 & 0.60 & 0.02 & -1.30 & 0.51 & 0.01 \\
Canopy cover (0-25\%) & -2.17 & 0.94 & 0.020 & -3.75 & 1.28 & 0.003 \\
Canopy cover $(25-50 \%)$ & -0.76 & 0.72 & 0.286 & -2.75 & 0.79 & $<0.001$ \\
Canopy cover $(50-75 \%)$ & 0.96 & 0.56 & 0.088 & -0.92 & 0.51 & 0.07 \\
Canopy cover (75-100\%) & 0.80 & 0.60 & 0.187 & -1.73 & 0.58 & 0.003 \\
Sex (Male) & 0.72 & 0.47 & 0.13 & 1.22 & 0.51 & 0.02 \\
Season $\times$ sex (spring as reference) & & & & & & \\
Summer & 1.69 & 0.45 & $<0.001$ & 0.82 & 0.36 & 0.02 \\
Summer $\times$ male & -0.75 & 0.55 & 0.17 & -0.85 & 0.52 & 0.10 \\
Fall & 1.32 & 0.43 & 0.002 & 0.06 & 0.36 & 0.87 \\
Fall $\times$ male & -2.08 & 0.55 & 0.001 & -1.00 & 0.57 & 0.08 \\
Winter & 0.67 & 0.42 & 0.11 & 0.19 & 0.35 & 0.59 \\
$\quad$ Winter $\times$ male & -1.30 & 0.52 & 0.01 & -1.25 & 0.54 & 0.02 \\
Body mass $(\mathrm{g})^{\mathrm{b}}$ & -0.15 & 0.13 & 0.24 & -0.28 & 0.13 & 0.03 \\
\hline Sping: March-May, sut
\end{tabular}

647 'Spring: March-May, summer: June-August, fall: September-November, winter: December648 January

$649{ }^{\mathrm{b}}$ The amount of change in the logit of overlap with $1 \mathrm{SD}$ change from its mean 
650 Table 2. Effects of environmental characteristics and squirrel factors on probability of crossing 651 random lines in forests by Mt. Graham red squirrels (Tamiasciurus hudsonicus grahamensis), 652 2008-2012, Mt. Graham, Arizona, USA.

\begin{tabular}{lccc}
\hline Variables & Estimate $^{\mathrm{a}}$ & $\mathrm{SE}$ & $P$ \\
\hline Distance to midden (m) & -0.47 & 0.10 & $<0.001$ \\
Maximum canopy cover (\%) & 0.89 & 0.37 & 0.02 \\
Slope & -0.50 & 0.28 & 0.07 \\
Distance to the nearest road (m) & 0.05 & 0.31 & 0.88 \\
Aspect (degree to north) & -0.01 & 0.07 & 0.88 \\
Distance to fire boundaries (m) & 0.03 & 0.24 & 0.90 \\
Season (spring as reference) & & & \\
Summer & 0.48 & 0.19 & 0.01 \\
Fall & 0.27 & 0.19 & 0.17 \\
Winter & 0.32 & 0.19 & 0.10 \\
Body mass (g) & -0.06 & 0.06 & 0.31 \\
Sex (Male) & -0.18 & 0.35 & 0.61 \\
\hline
\end{tabular}

$653{ }^{a}$ For continuous variables, estimate shows the amount of change in the logit of crossing with 1 654 SD change from its mean

655 bSpring: March-May, summer: June-August, fall: September-November, winter: December656 January 
657 Table 3. Effects of road characteristics and squirrel factors on rate of road crossing by Mt.

658 Graham red squirrels (Tamiasciurus hudsonicus grahamensis), 2008-2012, Mt. Graham, Arizona, 659 USA.

\begin{tabular}{|c|c|c|c|}
\hline Variables & Estimate $^{\mathrm{a}}$ & SE & $P$ \\
\hline \multicolumn{4}{|l|}{ Environment } \\
\hline Traffic- medium (low as reference) & 1.61 & 1.58 & 0.31 \\
\hline Traffic- high (low as reference) & 1.48 & 2.93 & 0.61 \\
\hline Distance to midden $(\mathrm{m})$ & -0.31 & 0.16 & 0.07 \\
\hline Mean slope & -0.37 & 0.38 & 0.34 \\
\hline Aspect (degree to north) & -0.06 & 0.29 & 0.83 \\
\hline Minimum road width (m) & 0.17 & 1.19 & 0.88 \\
\hline Maximum SD of tree height (m) & 0.80 & 0.11 & 0.01 \\
\hline \multicolumn{4}{|l|}{ Squirrel } \\
\hline Sex (Male) & -0.28 & 0.34 & 0.42 \\
\hline Body mass $(\mathrm{g})$ & 0.23 & 0.14 & 0.11 \\
\hline Mating season (spring \& summer) & 1.15 & 0.50 & 0.02 \\
\hline Presence of mates-distal ${ }^{\mathrm{b}}$ & 1.32 & 0.37 & $<0.001$ \\
\hline Number of mates-proximate & 0.42 & 0.16 & 0.008 \\
\hline
\end{tabular}

$660{ }^{a}$ For continuous variables, estimate shows the amount of change in the log transformed rate of 661 road crossing with 1 SD change from its mean

662 bresence of mates-distal: presence of potential mates on the other side of roads

663 'Number of mates-proximate: number of potential mates on resident side of roads 